\title{
The Canadian feminists' translation project: between feminism and postcolonialism
}

\author{
Simona Bertacco \\ University of Milan
}

\begin{abstract}
Paper
point de repère refathering remothering the landmark as the text in transit in translation from the writer to the reader remarks in passing the sign where myth and place no longer meet the blank expression which suddenly reveals the false logos of monologic speech the marching step that marks in place all time and space (Lola Lemire Tostevin, "Re")
\end{abstract}

In this article, Canada and Quebec are taken as case studies providing some interesting examples of inter-linguistic but intra-national translation, texts presenting features which can be addressed under the broad rubric of postcolonialism, especially as far as the power relations between the English and French languages in Canada are concerned. As a matter of fact, the socalled politics of translation appear only too clearly if we analyze the texts which are translated across the border between Canada and Quebec. Within this context, there has been a group of writers and scholars from both linguistic areas who have been willing to meet on a different ground - the ground of feminist writing and translation. Among the most important women in the group, Barbara Godard and Sherry Simon, as well as writers such as Nicole Brossard and Daphne Marlatt, deserve to be mentioned for the visibility their works have achieved in the past decades, and for the issues they raise.

\section{Introduction}

In the past two decades the discipline of Translation Studies has undergone a major shift from a purely or mostly linguistic interpretation of the process of translation, to a broader debate on the cultural and political agendas implicit in the practice of translation. Within this enlarged perspective, whereby translation is seen as a cultural practice invariably affected by social, political and ideological factors, the relevance of the notion of gender has been increasingly recognized. Essential to this opening up of Translation Studies to gender and feminist theory was the renewed interest in translation as rewriting, a notion we mostly owe to the work of André Lefevere: "Translation is the most obviously recognizable type of rewriting, and [...] it is potentially the most influential because it is able to project the image of an author and/or those works beyond the boundaries of their cul- 
ture of origins" (1992: 9). Lefevere erases the traditional opposition between original text and translated text and he highlights the points of touch rather than those of difference among the roles of the author, the translator and the literary critic (see Munday 2001: 128). Translations are shown to exist as material texts, documents that move, circulate, contribute to the making and the continuous alteration of our aesthetic taste. As a consequence, the intercultural communication that is carried out through translation marks not only an encounter but, more often than not, also a clash between the various discourses - dominant vs. 'minor' ones - which characterize every culture at any point in history (see Bianchi \& Demaria 2002: 21).

The 'rethinking' of translation brought about by theorists like André Lefevere and, more recently, Lawrence Venuti (see Lefevere 1992 and Venuti 1992, 1995) has highlighted the cultural and political agenda of translation and has brought with it a redefinition of the translating subject: who is translating and why? The issue of the subject's identity or cultural allegiance has always been a central concern of feminist theory and, in the 1990s, gender issues started to be recognized as relevant in Translation Studies as well. Feminist theorists establish a parallel between the status of the translated text, considered inferior to the original, and that of women, seen as inferior to their male counterparts. Identifying and criticizing "the tangle of concepts which relegates both women and translation to the bottom of the social ladder" (Simon 1996: 1) is the core of the feminist translation project on which I would like to focus my attention in this article. In particular, I intend to work on the contribution to the field of Translation Studies made by Sherry Simon and Barbara Godard and on the Canadian femininists' translation project that they, respectively, represent and discuss.

\section{A Canadian background}

If the cultures of Canada are [...] histories of various kinds, our attentions would be better directed toward the various utterances they make, the desires they articulate, and the responses they evoke. (Blodgett 1993: 8)

In 1969, the Official Languages Act in Canada institutionalized bilingualism as the country's official language policy. In his survey of Canadian literatures, both in English and in French, the critic E.D. Blodgett (1993: 10) goes back to Cartier's arrival to underline Canada's special link to translation, its historical need for translation resulting from the contact among its different cultures: native/colonial, English/French, English Canadian/Québécois. If in broad terms, translation is viewed as a social process that implies the transformation of texts and the values they convey from one context to another, in the Canadian context, translation embodies an act of production, not reproduction, of meaning, "a rite of passage, a process of transformation (hidden from the public eye, but protected by official sanction) which guarantees passage from one identity to another" (Simon 1990: 96). In other 
words, the Canadian subject contains borders within itself and for this reason it is not only capable but indeed in need of internal or intra-national translation.

The uniqueness of the Canadian situation is given by the non-territoriality of culture and language (see Söderlind 1991: 219), which is a common feature of postcolonial states which share the language with their previous dominators; but in Canada the situation is more complex because of the multiple pattern of society and because of a national policy aimed at preserving - through the institutional frame of multiculturalism - cultural difference. Canada is a bilingual yet multilingual nation for which we could speak of a general situation of polyglossia, even if the ethnic subject - that is, the subject whose mother tongue is neither English nor French - feels only a situation of diglossia. Thus, language in Canada represents a charged field and often becomes, in its literatures, the perfect tool for subversion and for the signification of otherness, resulting in a "limit writing, in an exploratory and innovative writing, the double-voiced writing of Bakhtin's carnivalesque subversion" (Godard 1990b: 155).

Given these preliminary considerations, it is not accidental that since the early 1990s, feminist translation theory has assumed a new role within Translation Studies thanks to the work of feminist critics and translators emerging from the Canadian context (people such as Sherry Simon, Barbara Godard, Kathy Mezei, Susanne de Lotbinière-Harwood, Daphne Marlatt). Interestingly, among the circumstances that have made such a phenomenon possible, a central role has been played by feminist experimental writers, meaning that feminist translation theory and feminist experimental writing, in Canada, have developed a special bond and shaped a border writing in which literary creation and translation meet (see Simon 1999: 58-60). Although it is indeed still possible - quite usual - to speak about Canadian literature in English and in French as of two completely separate cultural phenomena, a new commonality of themes and motifs has appeared in the last few decades which is directly linked to the postmodern questioning of language and of its (patriarchal) system of signification. Feminist writers' and feminist translators' problematization of language have made it possible to overcome the linguistic barrier between French and English cutting across Canada's cultural production and to create a vibrant, creative link between writing and translation. As Simon argues, "as literature becomes understood to be less the inspired creation of genius than a text made up of other texts, translation loses much of its devalorized 'secondary' nature to become a figure for all writing and a privileged player on the postmodern scene" (1990: 106).

Again, it is important to remind ourselves that Canada constitutes a special, even unique case. As we have seen, translation has played a special role in the definition of the cultural identity of the country; in particular, translation has always implied a direct commitment to certain literary discourses and a rejection of others. Translators have often been 'literary activists' in a sense (see Simon 1990: viii), fully aware of the way in which 
they were contributing to the intellectual debate and/or creating new lines of cultural production.

In an essay in which she provides a historical overview of the prefaces accompanying the novels in translation in Canada and Quebec, Simon notices an interesting fact about the Canadian situation: despite bilingualism, literary translations in Canada became an established given of the cultural production of the nation no sooner than the late 1960s, that is when the Canadian Government started financially supporting literary translation. Not only this, but also the dissymmetry of the two literary cultures with respect to their openness or closure to translation is telling. Till the mid-twentieth century, translation in Quebec showed a special interest in Anglo-Canadian works dealing with Quebec itself; whereas Anglo-Canadians, having their linguistic and cultural superiority secured by size and numbers, would freely translate any work that would make Quebec culture more accessible to an English-speaking audience (Simon 1990: 113). The conclusions that Simon draws from this situation are particularly interesting and deserve quoting at length:

Prefaces in Canadian translations have clearly focused on the collective context. They define the 'knowledge' which translations are supposed to furnish in terms of the specific needs of the group. The decision of the Canadian government to fund literary translation is therefore quite congruent with the perspective in which translation has been carried out in English Canada from the start - literary translation is carried out within explicitly social and political parameters. (1990: 115)

Clearly in Canada the political agenda of translation cannot be hidden, owing to the tense and conflictual relation between the two - official - souls of the nation and, clearly again, it has had an impact on the literary parameters concerning which works are or are not to be translated, and on the literary production of Canada as a whole. This, as I hope to show in this article, is a quintessentially Canadian phenomenon, and provides us with a unique test ground to study the impact of feminism and postcolonial discourse on translation.

\section{The Canadian feminists' translation project}

What has emerged from this double context is, significantly, a theory of feminist translation that links issues of identity and difference to a postcolonial critique of dominant languages and national cultures. In fact, there is a striking analogy between the reading of translation in postcolonial theory as a forced replacement of the linguistic and cultural 'difference' of the foreign text and the notion of assertive manipulation of the text to be translated, or the 'womanhandling' of the text - as Godard calls it - practiced by Canadian feminist translators: "The feminist translator, affirming her critical dif- 
ference, her delight in interminable re-reading and re-writing flaunts the signs of her manipulation of the text" (1990a: 91).

The violence of translation has become a significant feature of any practice of translation taking place within marginal or minority cultures. Within such contexts, the subversion of language in and through translation is not seen as mere linguistic experimentation. Instead it is to be read as a practice aimed at the representation of difference. As translator de Lotbinière-Harwood openly admits, "My translation practice is a political activity aimed at making language speak for women. So my signature on a translation means: this translation has used every translation strategy to make the feminine visible in language" (qtd. in Gauvin 1989: 9) (emphasis added).

Barbara Godard is one of the most authoritative voices on the issue of feminine and feminist writing in Canada. A bilingual herself, she is well known both as a literary critic and as the English translator of some of the most important Québécois women writers. In 1984, she founded the feminist literary magazine Tessera - which deals with the issue of translation within Canada and within the Canadian feminist community - and she has always accompanied her work as a translator with a meta-reflection that she has collected in numerous essays, prefaces and in a "translator's journal" (Godard 1995). Godard always highlights her gender as a translator. In one of her essays, "Theorizing Feminist Discourse/Translation", she focuses on the complicity between avant-garde feminist writing and feminist translation: "Both theoreticians of women's discourse and of feminist translation ground their reflection in issues of identity and difference, otherness being framed linguistically in terms of gender as well as nationality" (Godard 1990a: 87). The core issue is how the difference or otherness of the subject can be reconstructed in language. Feminist discourse, Godard argues,

seeks to expose ideological modes of perception through an expansion of messages in which individual and collective experiences originate from a critical stance against the social contexts of patriarchy and its language. In this, feminist texts generate a theory of the text as critical transformation. (1990a: 88)

Like Canadian discourse and feminist discourse, translation's word is double, "it is the echo of the self and the other" (1990a: 88), and it is for this reason that women writers often make use of the image of translation as a metaphor for their difficult relationship to language and self-expression. Now if, as I said earlier, the parallel established between woman and translation is supposed to bear a negative value - with 'woman' and 'translation' being the negative poles of the dichotomy - it becomes a positive image for the self-conscious feminist translator who is actively signifying her difference through her work. In this perspective, translation detaches itself more and more from the ideal of the quest for equivalence and, instead, presents transformation as performance as its model (Godard 1990a: 91). By referring to the work of the Québécois writer Nicole Brossard, Godard qualifies 
translation as 'transformance', "to emphasize the work of translation, the focus on the process of constructing meaning in the activity of transformation, a mode of performance" (1990a: 90).

In her translator's journal, pinpointing her questions and doubts when she was translating the novel Picture Theory by Nicole Brossard, Godard focuses on the issue of woman's identity. Referring to Picture Theory, she writes: "This is a novel which calls out for its translation as the implied reading of its textual system" (Godard 1995: 73). One of the central themes of the novel is how a woman can think of herself in language in general and in the various national languages: "What would she be if she thought of herself in English? In French? In Italian? How would a woman be thought in these languages? In language 'tout court'?" (1995: 73) If, as Godard says, experimental feminist texts call out for their own translation, they call out for specific translators as well. The issue of gender is the key element, indeed it is what makes and marks the difference between a traditional or equivalenceoriented translation practice, and one that is grounded in a communal project of feminist reanimation of language and cultural values. Clearly, gender is not always foregrounded in writing or in translation; but when it is, it brings with it an overtly political, as well as literary, project. In other words, it requires "the replacement of the modest, self-effacing translator. Taking her place would be an active participant in the creation of meaning who advances a conditional analysis" (Godard 1995: 94). The importance of a common project cannot be stressed enough in my opinion. As Antoine Berman argues: "Every significant translation is grounded in a project, in an articulated goal. This project is determined by both the position of the translator and by the specific demands of the work to be translated" (1995: 76). The position given to the translator in Godard's theory seems to be grounded in the concrete experience shared by the writers and theorists who used to gather around the literary journal Tessera in the early 1980s and its translation of Anglo- and Franco-Canadian feminist writings. The interweaving of writing and theory provided the common ground for this experience and is clearly reflected in the prefaces to the translations made by these women:

Translation here is a practice of reading/writing and, as such, the historical adventure of a subject. The modest self-effacing translator, corollary to the notion of transparency, is replaced by a translator who is an active participant in the creation of meaning, and may even immodestly flaunt her signature in a preface. (Godard qtd. in Brossard 1986: 7)

This method and this translation project are clearly exemplified by Godard's experience as the translator of the works of Quebec feminist writer Brossard. Brossard has published seven novels and numerous collections of poems. She is well-known for her linguistic experimentation: in her works, the 'womanhandling' of the linguistic medium is the most significant feature both at the level of content and of form, since it is the material site through which the meaning of the text is produced and shaped. Brossard enjoys 
mixing different languages in her texts (Picture Theory, for instance, bears an English title even though it is written mostly in French): French, English, joual. She also subverts the surface of language through the forced injection of feminine gender markers (a supplementary feminine $-e$ in French even where unneeded). She normally collaborates with the translators of her works, as Barbara Godard's translator's journal demonstrates:

\section{August 1989.}

There was a letter today from Nicole Brossard asking when I was coming to Montreal to discuss the translation. In the past, we have met in a café for several hours to talk through some of the ambiguities after I have worked through several drafts. Tonight, I telephoned her to explain my hopes of going to Montreal in late August. If this is not possible, I shall mail her the material about which I have questions. We talked about the problem of writing/translating the book. The problem of remembering the wording used for a phrase pages earlier. How did she organize this? Like Doré Michelut editing her text on the wall? Walking around and viewing all the sections at once?

"No," replied Nicole, just turning back to those earlier pages and looking up the word. Exactly what I've been doing. (Godard 1995: 74-75)

As is clearly shown in the above quotation, the translator is creatively rewriting Brossard's text into her own, an activity in which not only her subjective identity is deeply involved, but also the thick web of social discourses surrounding the work of translation.

As far as the textual strategies adopted by Godard as a translator are concerned, we can say that she studies and eventually follows the way in which the writer creates meaning in the original text, that is she plays with the signifier, with the graphic layout of the text, with the resulting semantic ambiguity, in order to lead the reader to focus on language and its conventions. A quick example from Godard's translation of Brossard's novel L'Amèr is representative of how Godard goes about her rewriting activity. By pronouncing aloud the word 'Amèr' in French, we obtain up to three different semantic options:

- bitter

- mother

- sea

The outcome in Godard's English translation (Brossard 1983: title page) has to grapple with the grammatical difference between the English and French languages in relation to the gender of nouns: since English nouns do not follow natural gender like the French ones, the feminization of the text has to make use of different strategies in order to achieve the effect of the source text. In translating the title of Brossard's novel, Barbara Godard extends her translation strategies to the manipulation of the layout of the types on the white page. The final result is a chain of words united by a huge ' $S$ ' in the 
middle, enabling two possible readings of the same title as 'These Our Mothers' and 'These Sour Smothers'.

Interestingly, Godard's reflections are very well grounded in her 'lived' experience as an active translator. If it is important to acknowledge gender as part of her identity as a translator, it is equally important to reflect on the general lesson on translation that we can extract from her reading. Her questions and doubts concerning the smallest aspects of textuality in the works she translates, her dissatisfaction with the precariousness of any expression, the issues she raises about identity and difference are shared by many translators inside and outside the field of feminist writing:

No final version of the text is ever realizable. There are only approximations to be actualized within the conditions of different enunciative exchanges. As such, translation is concerned not with 'target languages' and the conditions of 'arrival' but with the ways of ordering relations between languages and cultures. Translation is an art of approach. (Godard 1995: 81)

Now, in the case of the texts by Brossard, there can be no doubt concerning the shared intentionality of writer and translator. But, since not all women writers are also feminist writers, what happens when, as Simon exemplifies (Simon 1996: 15) in her Gender in Translation, the writer's intention has been forced by the translator's? This aggressive form of translation bears the name of 'hijacking'. The example given by Sherry Simon is that of the novel Lettres d'une autre by Quebec writer Lise Gauvin and translated into English by Susanne de Lotbinière-Harwood. In French, the third-person personal pronoun $i l$ serves both to express a male subject or a generic, genderless one. Surprisingly enough - or not surprisingly at all if we are already familiar with the translator's signature - the same pronoun used generically is changed into the feminine she in the English version of the novel (Letters from Another). In the preface to her translation, de Lotbinière-Harwood writes: "my signature on a translation means: this translation has used every translation strategy to make the feminine visible in language" (qtd. in Gauvin 1989: 9).

\section{Postcolonial enlargements}

In general, as far as feminist translation is concerned, there is a good level of coincidence between the writer's and the translator's intentions. We could even go as far as saying that feminist translation can be seen as an extension or a further development - within a new cultural context - of the original text's intention. And it is not at all surprising that the most successful examples of feminist translation are those in which the original text and the translated one converge towards a common goal, namely the subversion of the patriarchal vision of the world. We can stay assured that innovative or avantgarde feminist texts will be best translated by translators willing to try their 
hand at verbal experimentation and playfulness, rather than by translators opting for mere conceptual equivalence. In these texts, at least in the ones described above, the signature of the translator becomes as important as that of the writer. And both writer and translator seem to be happy with this state of affairs.

However, are we to conclude that this is always the right or the best solution? Does the translator simply have the right to counteract the author's intention whenever s/he wants? What happens, say, if a Western woman translates, not the works of a man for whom gender issues, to put it simply, have never existed, but the works of an African feminist writer whose feminism is simply different and does not coincide with the translator's own notion of it? As Kirsten Holst Petersen points out about African women's feminist consciousness, "One obvious and very important area of difference is this: whereas Western feminists discuss the relative importance of feminist versus class emancipation, the African discussion is between feminist emancipation versus the fight against neo-colonialism, particularly in its cultural aspect" (1995 [1984]: 251-2).

These questions shift the focus away from translation within a Western feminist perspective and enlarge the angle of vision to include the translation of works from postcolonial nations into the language of the former colonizer (English, French, Spanish, Portuguese, ... Italian). This shift in focus may appear to be a partial detour from the topic of this article, but it is in my opinion entirely justified for a country such as Canada that has found reinvigorating energy in the postcolonial interpretation of its linguistic and cultural complexities. Moreover, through a postcolonial enlargement of the issue of feminine/feminist writing, I would like to focus my attention on the ethical import of the translation project analyzed in these pages and to put forward some concluding remarks on the advancement of the debate around the issues of translation in Canada.

By trying to provide an answer to the questions posed above, we are inevitably urged to consider the translation strategies described in this paper from a different perspective, one that admits that there is not just one type of feminism in the world, and that there may be novels and poems that we, as Western subjects, read as examples of feminine if not feminist writing, but that were not conceived in this way by their authors. An aggressive "womanhandling' of such texts would be seen as a forceful deviation from the writer's intention and her creative project. In her essay "The Politics of Translation" (2000 [1993]), Spivak attacks Western feminists who expect feminist writing from all over the world to conform to the same ideological pattern and to be easily translated into the language of colonial rule, English. Such translations, while granting the texts a wide circulation over the entire English-speaking world, eliminate the identity of the less powerful cultures. In her words:

In the act of wholesale translation into English there can be a betrayal of the democratic ideal into the law of the strongest. This happens when all the li- 
terature of the Third World gets translated into a sort of with-it translatese, so that the literature by a woman in Palestine begins to resemble, in the feel of its prose, something by a man in Taiwan. (2000[1993]: 399-400)

Spivak insists that Western feminists should learn the languages in which postcolonial feminist writers write, that they should not contribute to the hegemony of English and French, by assimilating local situations and motifs to make them accessible to the Western readers, but should on the contrary attempt to capture the difference of, say, the Bengali, the Somali, the Pakistani view. What Spivak advocates is a translation strategy aimed at understanding the language, the worldview and the situation of the original.

Spivak's argument is highly controversial, for if pushed to its further consequences, it would call in doubt the very existence of translation tout court, advocating a kind of cultural purism which would result in an anachronistic form of isolationism. As a matter of fact, as Susan Bassnett and Harish Trivedi point out in the introduction to their volume Post-Colonial Translation:

In current theoretical discourse, then, to speak of postcolonial translation is little short of tautology. In our age of (valorization of) migrancy, exile, and diaspora, the word 'translation' seems to have come full circle, and reverted from its figurative literary meaning of an interlingual transaction to its etymological physical meaning of locational disrupture; translation seems to have been translated back to its origins. (1999: 13)

However, Spivak's formulation of the problems of postcolonial feminist translation is useful to highlight the asymmetric power relations which surround and determine all the cultural productions of our age. It also provides an instructive reminder for us readers when approaching postcolonial texts in their English translation, urging us to look at the translated text as a battleground between English and the other languages. In Canada, this battleground occurs within the geographical borders of the nation and the asymmetry in terms of linguistic and cultural power is embodied in the relation between Quebec and "Canada Outside Quebec", as Charles Taylor would have it (see Taylor 1992). In other words, the Canadian feminists' translation project is interesting not only as an illustration of the importance of a shared project between writer and translator, but also insofar as it can only be fully understood and appreciated if gauged against the Canadian background.

By taking place - significantly - within a translation process, the meeting of the two Canadian 'solitudes' in the texts translated from French into English turns out to be all but politically neutral: the Canadian feminists' translation practice, by flaunting its operating strategies and its partiality instead of concealing it, is extremely relevant to the discourse of the cultural and political agenda that translation can serve. Culturally, this body of work shows translation inhabiting the border between literary creation and literary criticism or theory in a country where translation is itself an institu- 
tion; politically, it points to the need to let the marginal voices within each culture speak in a way that is capable of transforming the target culture. In the texts analyzed this opening-up of a new discursive space is made possible by the translation strategy adopted, a strategy that does not aim at naturalizing the foreign, but that instead "receives the foreign as foreign" (Berman 2000 [1985]: 285) by transforming, through an intensive "labor on the letter" (297) the target language.

Flaunting the difference or foreignness of the text means also inviting a different approach to the translated text, one that takes in, besides the name of the author, the other signature on the cover page and, even better, the hints the translator gives us as to how she or he has worked upon the text. Whichever way we put it, these forms of mise en abyme of literary and cultural translation have a great cultural value if they succeed in reminding us that all literary exchanges - translations included - are subjected to a wide range of ideological agendas.

\section{Conclusion}

For the purpose of this paper, the linking of feminism, colonization and translation provides a way to look at the complex tangle of discourses that the analysis of translation from a cultural studies perspective can help illuminate. The Canadian feminists' translation project that I have tried to describe provides no universal solution to the problems surrounding the translation of women's texts. However, it provides an example of a "minoritizing translation" which Venuti sees as the only form of rewriting capable of promoting, simultaneously, cultural renewal and cultural difference (1998: 11). At the basis of the textual practices analyzed, there lies an 'ethics of difference', where difference stands for the valorization of the cultural alterity or newness of the source text, but also for the formal principle working to destabilize standard language, standard genres, standard values in the target culture. It is such an ethics that Venuti and Berman see as the hopeful resource of translation in our globalized world, because it provides a form of resistance to the total homogenization of textual practices and it puts an emphasis on the creative power of translation.

In Canada, translation is part of the country's institutional asset and, as such, it has been instrumental to fixing and maintaining the cultural identity within each linguistic group. Indeed, even the choice of which texts to translate can work to consolidate the literary canon, cultural identity, or the conceptual paradigms in use within the local community. However, the opposite is also possible and translation can be used as a tool to open up a new intellectual and cultural dialogue within the nation. What emerges from the Canadian feminists' translation project is an instance of translation as a form of literary and cultural agency or performance. Quebec feminist writers translated by fellow English-Canadian women writers, literary critics and translators are given the chance to influence English-Canadian literature, 
its forms and paradigms, and to bring new life to the intellectual debate between the two parts of the nation.

Feminism provides a common ground in the case of the writers analyzed here, a set of values held in common, making the transition between one side of the border and the other easier. But, clearly, it is not the only possible one and could be replaced by, for instance, the will to resist any form of racism or cultural narcissism in the translation of postcolonial literatures. Besides their feminism, however, the women involved in the Canadian feminists' project also share a common vocabulary pertaining translation and its role in shaping cultural identities. In the first place, they see translation as a textual practice that is significant and contingent in their everyday experience of the world. It is part of their 'Canadianness', engrained in their experience as writers and critics in contemporary Canada. Such an openness to translation as a signifying textual practice enables the interplay between writing and translation that we have seen in these women's work, and it provides a context to their literary experiments, revealing them to be invaluable elements for the study and knowledge of Canadian culture in its entirety.

\section{Bibliography}

\section{Primary texts}

Brossard, Nicole ((1988)[1977]). L'amèr ou Le chapitre effrité. Montréal: typo L'Exagone.

Brossard, Nicole (1983). These Our Mothers Or: The Disintegrating Chapter. (tr. Barbara Godard). Toronto: Coach House Press.

Gauvin, Lise (1989). Letters from Another. (tr. Susanne de Lotbinière-Harwood). Toronto: Women's Press.

Godard, Barbara (1990a). "Theorizing Feminist Discourse/Translation." S. Bassnett $\&$ A. Lefevere (eds) (1990). Translation, History and Culture. London/New York: Pinter, 87-96.

Godard, Barbara (1995). “A Translator's Journal.” S. Simon (ed.) (1995). Culture in Transit: Translating the Literature of Quebec. Montreal: Véhicule Press.

\section{Secondary texts}

Bassnett, Susan \& André Lefevere (eds) (1990). Translation, History and Culture. London/New York: Pinter.

Bassnett, Susan \& Harish Trivedi (eds) (1999). Post-Colonial Translation: Theory and Practice. London/ New York: Routledge.

Berman, Antoine ((2000)[1985]). "Translation and the Trails of the Foreign." (tr. Lawrence Venuti). L. Venuti (ed.) (2000). The Translation Studies Reader. New York/London: Routledge, 284-297.

Berman, Antoine (1995). Pour une critique des traductions. Paris : Gallimard.

Bianchi, Cinzia, Demaria, Cristina \& Siri Nergaard (eds) (2002). Spettri del potere. Ideologia, identità, traduzione negli studi culturali. Rome: Meltemi. 
Blodgett, Edward Dickinson (1993). "Is a History of the Literatures of Canada Possible?" Essays on Canadian Writing 50, 1-18.

Godard, Barbara (1990b). "The Discourse of the Other: Canadian Literature and the Question of Ethnicity." The Massachusetts Review 31, 153-184.

Godard, Barbara (ed.) (1994). Collaboration in the Feminine: Writings on Women and Culture from Tessera. Toronto: Second Story Press.

Lefevere, André (1992). Translation, Rewriting and the Manipulation of Literary Fame. London/New York: Routledge.

Munday, Jeremy (2001). Introducing Translation Studies: Theories and Applications. London/New York: Routledge.

Simon, Sherry (1990). "Rites of Passage: Translation and Its Intents." The Massachusetts Review 31, 96-110.

Simon, Sherry (ed) (1995). Culture in Transit: Translating the Literature of Quebec. Montreal: Véhicule Press.

Simon, Sherry (1996). Gender in Translation: Cultural Identity and the Politics of Transmission. London/New York: Routledge.

Simon, Sherry (1999). "Translation and Creation in the Contact Zone: Border Writing in Quebec." S. Bassnett \& H. Trivedi (eds) (1999). Post-Colonial Translation: Theory and Practice. London/New York: Routledge, 58-74.

Petersen, Kirsten Holst. ((1995)[1984]). "First Things First: Problems of a Feminist Approach to African Literature." B. Ashcroft, G. Griffiths \& H. Tiffin (eds) (1995). The Post-Colonial Studies Reader. London/New York: Routledge, 251-54.

Söderlind, Sylvia (1991). Margin/Alias: Language and Colonization in Canadian and Québécois Fiction. Toronto/Buffalo/London: University of Toronto Press.

Spivak, Gayatri ((2000)[1993]). “The Politics of Translation.” Lawrence Venuti (ed.) (2000). The Translation Studies Reader. London/New York: Routledge, 397416.

Taylor, Charles (1992). Multiculturalism and the 'Politics of Recognition.' Princeton: Princeton University Press.

Tostevin, Lola Lemire (1994). "Re." B. Godard (ed.) (1994). Collaboration in the Feminine: Writings on Women and Culture from Tessera. Toronto: Second Story Press, 40-43.

Venuti, Lawrence (ed.) (1992). Rethinking Translation. London/New York: Routledge.

Venuti, Lawrence (1995). The Translator's Invisibility: A History of Translation. London/New York: Routledge.

Venuti, Lawrence (1998). The Scandals of Translation: Towards an Ethics of Difference. London/New York: Routledge.

Venuti, Lawrence (ed.) (2000). The Translation Studies Reader. London/New York: Routledge. 